\title{
Yield, Quality, Economics and Nutrient uptake of Onion (Allium cepa L.) Influenced by Organic Nitrogen Management
}

\author{
R. N. Meena*, Ashvin Kumar Meena and Kalyan Singh \\ Department of Agronomy, Institute of Agricultural Sciences, Banaras Hindu University- \\ Varanasi-221005, (U.P.), India
}

*Corresponding author

\section{A B S T R A C T}

\section{Keywords}

Organic treatments,

Economic returns,

Poultry manure

Article Info

Accepted:

04 September 2019

Available Online:

10 October 2019
A field experiment was conducted during summer season of 2004 and 2005 to find out the effect of various sources (FYM, VC and PM) and rates of organic manures (100\%, 125\%, $150 \%$ RND) on yield, quality and economics of onion (Pusa Red) on a sandy clay-loam soil low in available $\mathrm{N}$ and medium in available phosphorus and potassium. Pooled data analysis revealed that the application of organic manure significantly influenced the yield attributes and bulb yield of onion over $100 \%$ RND as urea (control). Progressive increase in dose of all the organic manures significantly increased the bulb yield, haulm yield, pungency $(\%)$ and nutrient uptake (NPK). The application of $150 \%$ RND as poultry manure gave higher bulb (270.84 $\left.\mathrm{q} \mathrm{ha}^{-1}\right)$ and haulm yields $\left(35.13 \mathrm{q} \mathrm{ha}^{-1}\right)$ than other sources and levels of organic manures. Soil physical parameters viz. bulk density and water stable aggregates did not showed any profound effect due to addition of organic materials. The maximum organic carbon build up was occurred (0.54\%) when 150\% RND was supplied through PM $\left(\mathrm{T}_{4}\right)$. Soil biological properties showed improvement in the soil microbial counts over its initial values at the end of 2-years due to supplementation of organic sources. All the organic treatments recorded higher economic returns over control and the highest net returns (Rs. 74,233 ha ${ }^{-1}$ ) was obtained due to $100 \%$ as poultry manure followed by $125 \%$ RND as poultry manure (Rs. $72,195 \mathrm{ha}^{-1}$ ) which was 105.05 per cent higher than control (Rs. 36,202 ha-1). The net benefit-cost ratio was also highest with $100 \%$ RND applied as poultry manure (2.33).

\section{Introduction}

Onion (Allium cepa L.) is one of the most important commercial vegetable crops grown extensively throughout the country. India ranks first in area (0.49 $\mathrm{m} \mathrm{ha}$ ) and second in production (4.9 $\mathrm{m}$ tonnes) of onion bulbs in the world. Uttar Pradesh ranks third (12.46\%) in onion production after Maharashtra (23\%) and Gujarat $(16.86 \%)$. The annual production of onion in the world is about 35 tonnes and India accounts $16 \%$ of the total world production and ranks second after China. Besides, $70 \%$ of foreign exchange earnings 
among fresh vegetables come from only onion (Fageria, 2003). The continuous chemical fertilizer use deteriorated crop while organic manures improved these properties (Watson et al., 2002). The farmers can in turn obtained good remuneration from the organically produced vegetables due to their heavy demands in national and international markets (Singh, 2005). Adoption of organic vegetable production would largely depend upon supplies of organic inputs, thoroughly backed up by well-proven production technologies. Judicious use of organic manures can maintain long term soil fertility and sustain higher productivity of crops. Nitrogen is considered to be the most limiting factor realizing higher yields. An adequate supply of nitrogen to onion is associated with efficient source to sink relationship leading to higher productivity. The present investigation was therefore conducted to study the effect of different organic nitrogen nutrition sources on yield attributes, yield and quality of onion in agro-ecology of eastern Uttar Pradesh.

\section{Materials and Methods}

A field experiment was conducted during the winter seasons of 2004 and 2005 at the Research Farm, Institute of Agricultural Sciences, BHU, Varanasi. The soil was sandy clay loam in texture having $\mathrm{pH} 7.12$, organic carbon $0.45 \%$ and EC $0.32 \mathrm{dSm}^{-1}$. The available $\mathrm{N}, \mathrm{P}$ and $\mathrm{K}$ contents of soil were $180.50,18.46$ and $202.42 \mathrm{~kg} \mathrm{ha}^{-1}$, respectively. The water holding capacity, bulk density and porosity of the surface soil $(0-15 \mathrm{~cm})$ were $40.86 \%, 144 \mathrm{~g} \mathrm{cc}^{-1}$ and $42.40 \%$, respectively. A set of 10 treatments comprising 3 different rates i.e. $100 \%, 125 \%$ and $150 \%$ of recommended nitrogen dose (RND) and 3 sources of organic manures viz., farmyard manure (FYM), vermicompost (VM) and poultry manure (PM) were compared with recommended nitrogen dose given through urea (control). The experiment was laid out in a randomized block design with 3 replications in fixed plots in both the years. The nutrient contents of the organic manures were applied on dry weight basis. The organic manures were applied as per treatment 15 days before sowing and mixed thoroughly in $15 \mathrm{~cm}$ top soil layer. In control treatment, recommended dose of nitrogen through urea was drilled at sowing, $10 \mathrm{~cm}$ deep and $5 \mathrm{~cm}$ away from seed. The NPK contents of FYM, VM and PM were $0.50,2.30$ and $2.80 \% \mathrm{~N}, 0.20,0.75$ and $2.20 \%$ $\mathrm{P}_{2} \mathrm{O}_{5}$ and $0.50,1.23$ and $1.30 \% \quad \mathrm{~K}_{2} \mathrm{O}$, respectively. Sixty days old seedlings of 'Pusa Red' were transplanted at 20x10 cm spacing on 26 and $20^{\text {th }}$ February, in 2004 and 2005, respectively. The crop was harvested ninety days after transplanting in both the years on 30 May and 28 May during 2004 and 2005, respectively. Standard agronomical practices were followed to grow successful crop during both the years. The data on days to $50 \%$ bulb formation, bulb diameter, bulb and haulm yields were recorded. The samples were analyzed separately for $\mathrm{N}, \mathrm{P}$ and $\mathrm{K}$ contents after drying it in an oven, ground properly in a Wily mill to pass through a 30 mesh sieve. Carbohydrate content (\%) was determined using method described by Loomis and Shull (1937). Pungency (\%) was computed by Allylpropyl-disulphide content in onion bulb determined as Pyruvic acid using formula suggested by Hort and Fisher (1970). Economics of the treatments were computed on the basis of prevailing market rates of produce and agro-inputs. As the trend of data was similar in both the years, pooled data are presented.

\section{Results and Discussion}

\section{Effects on yield attributes and yield}

The application of $150 \%$ RND as poultry manure recorded maximum bulb diameter and achieved $50 \%$ bulb-formation stage significantly early compared to other treatments (Table 1). It is clear from the data that the bulb and haulm yields were 
significantly influenced by different treatments of organic nitrogen. The maximum bulb yield (270.84 $\mathrm{q} \mathrm{ha}^{-1}$ ) was recorded with the application of $150 \%$ RND as poultry manure which was significantly better than control $\left(236.30 \mathrm{q} \mathrm{ha}^{-1}\right)$. The increase in bulb yield due to $150 \%$ RND through PM was $14.62 \%$ higher over control. In general, the significant improvement in yield attributes of onion with organic nitrogen fertilization could be ascribed to overall improvement in vigour and crop growth. The increase in yield may be due to better root proliferation, enhanced nutrients uptake and water, higher leaf number, more photosynthesis and accelerated rate of food assimilation (Yadav et al., 2005). Increasing levels of organic nitrogen also increase bulb and haulm yields irrespective of sources. This could be attributed to increased vegetative growth possibly a result of effective utilization of nutrients absorbed and a result of improved nourishment through $\mathrm{N}$-fertilization (Bhakher et al., 1997). In general better performance of PM on yield was probably due to higher rate of mineralization (Azad and Lehria, 2001; Babu et al., 2002 and Chettri et al., 2002).

\section{Effect on quality}

Significantly higher values of quality parameters viz., pungency percentage was recorded with the application of poultry manure followed by vermicompost and FYM compared to control (Table 2). Application of organic $\mathrm{N}$ significantly increased the allypropyl disulphide content in onion bulb and the maximum value was recorded with the application of $150 \%$ RND as poultry manure. Application of organic $\mathrm{N}$ at higher rates also significantly increased the ally-propyl disulphide content in onion. Carbohydrate (\%) did not produce any significant difference due to various organic sources and their application rates. Increasing organic $\mathrm{N}$ increased volatile and fatty oil contents resulting in significantly higher production of ally-propyl disulphide in onion bulb. These results are in close agreement with findings of Singh et al., (1996).

The mean total uptake of nitrogen, phosphorus and potassium by onion was significantly highest under all organic treatments compared to control and the highest uptake $(42.03 \mathrm{~N}$, $41.81 \quad \mathrm{P}_{2} \mathrm{O}_{5}$ and $77.23 \quad \mathrm{~K}_{2} \mathrm{O} \quad \mathrm{kg} \quad \mathrm{ha}^{-1}$ respectively) was recorded with PM @ $150 \%$ RND.

\section{Soil properties}

Soil physical parameters viz. bulk density and water stable aggregates did not showed any profound effect due to addition of organic materials (Table 3). The values of chemical properties of soil like organic carbon, available $\mathrm{N}, \mathrm{P}$ and $\mathrm{K}$ increased significantly from initial stage and over control treatment on the completion of 2 years cycle of ricetable pea-onion sequence. The maximum organic carbon build up was occurred $(0.54 \%)$ when $150 \%$ RND was supplied through PM $\left(\mathrm{T}_{4}\right)$ while the least value $(0.40 \%)$ was noticed with the $100 \%$ RND through urea $\left(\mathrm{T}_{10}\right)$. The organic carbon of the soil increased over its initial status $(0.38 \%)$ under nitrogen supply through organic sources. The nutrient status of the experimental site was also affected significantly by the application of different organic manures along with their varying rates. Results clearly indicated improved fertility status of soil due to increased values of available $\mathrm{N}, \mathrm{P}$ and $\mathrm{K}$ in all organic treatments over its initial value as well as control.

Application of organic manures with increased rate enhanced soil fertility over their lower doses. At the end of 2-year sequence, $150 \%$ RND applied as PM maintained higher values of organic carbon and available $\mathrm{N}, \mathrm{P}$ and $\mathrm{K}$. 
Table.1 Effect of organic nitrogen management on yield and economics of onion (pooled data over 2 years)

\begin{tabular}{|c|c|c|c|c|c|c|c|c|c|}
\hline & $\begin{array}{c}\text { Days to } \\
50 \% \text { bulb } \\
\text { formation }\end{array}$ & $\begin{array}{c}\text { Bulb } \\
\text { diameter to } \\
50 \% \text { bulb } \\
\text { formation } \\
\quad(\mathrm{cm})\end{array}$ & $\begin{array}{l}\text { Bulb diameter } \\
\text { at } 15 \text { days after } \\
50 \% \text { bulb } \\
\text { formation } \\
(\mathrm{cm})\end{array}$ & $\begin{array}{c}\text { Onion } \\
\text { yield (q } \\
\left.\text { ha }^{-1}\right)\end{array}$ & $\begin{array}{c}\text { Haulm } \\
\text { yield } \\
\left(\mathbf{q} \text { ha }^{-1}\right)\end{array}$ & $\begin{array}{l}\text { Total cost } \\
\left(\text { Rs. } \text { ha }^{-1}\right)\end{array}$ & $\begin{array}{c}\text { Gross } \\
\text { return } \\
\left(\text { Rs. } \text { ha }^{-1}\right)\end{array}$ & $\begin{array}{l}\text { Net return } \\
(\text { Rs. ha } \\
\text { hi })\end{array}$ & $\begin{array}{l}\text { Benefit } \\
\text { cost ratio }\end{array}$ \\
\hline $\begin{array}{l}\text { T }_{1}-100 \% \text { RND as } \\
\text { FYM }\end{array}$ & 60.08 & 1.58 & 3.79 & 239.31 & 13.76 & 31788 & 95724 & 63936 & 2.01 \\
\hline $\begin{array}{l}\mathrm{T}_{2}-125 \% \text { RND as } \\
\text { FYM }\end{array}$ & 60.76 & 1.65 & 3.88 & 245.35 & 18.27 & 34288 & 98140 & 63852 & 1.86 \\
\hline $\begin{array}{l}\text { T }_{3}-150 \% \text { RND as } \\
\text { FYM }\end{array}$ & 61.26 & 1.72 & 3.93 & 250.64 & 19.60 & 36788 & 100256 & 63468 & 1.72 \\
\hline $\begin{array}{l}\mathrm{T}_{4}-100 \% \text { RND as } \\
\text { VM }\end{array}$ & 62.42 & 1.75 & 4.08 & 254.63 & 20.36 & 31787 & 101852 & 70065 & 2.20 \\
\hline $\begin{array}{l}\mathrm{T}_{5}-125 \% \text { RND as } \\
\text { VM }\end{array}$ & 62.71 & 1.92 & 4.32 & 259.24 & 24.65 & 34289 & 103696 & 69407 & 2.02 \\
\hline $\begin{array}{l}\mathrm{T}_{6}-150 \% \text { RND as } \\
\text { VM }\end{array}$ & 63.15 & 2.06 & 4.60 & 262.22 & 26.83 & 36788 & 104888 & 68100 & 1.85 \\
\hline $\mathrm{T}_{7}-100 \%$ RND as PM & 63.46 & 2.18 & 4.71 & 265.05 & 28.83 & 31787 & 106020 & 74233 & 2.33 \\
\hline $\mathrm{T}_{8}-125 \%$ RND as PM & 64.60 & 2.26 & 4.79 & 266.21 & 30.83 & 34289 & 106484 & 72195 & 2.10 \\
\hline $\mathrm{T}_{9}-150 \%$ RND as PM & 65.27 & 2.38 & 4.93 & 270.84 & 35.13 & 36788 & 108336 & 71548 & 1.94 \\
\hline $\begin{array}{l}\mathrm{T}_{10}-100 \% \quad \mathrm{RND} \\
\text { through urea }\end{array}$ & 59.17 & 1.53 & 3.45 & 236.30 & 11.27 & 22873 & 59075 & 36202 & 1.58 \\
\hline $\mathrm{SEm} \pm$ & 0.33 & 0.16 & 0.26 & 5.77 & 2.87 & & & & \\
\hline C.D. (0.05) & 0.99 & 0.48 & 0.77 & 11.70 & 5.81 & & & & \\
\hline
\end{tabular}

Market price of onion bulb (organic) Rs. $400 \mathrm{q}^{-1}$, Onion bulb (inorganic) Rs. $300 \mathrm{q}^{-1}$, Cost (Rs. quintal ${ }^{-1}$ ): FYM -50 , VM -300 , PM -300 and Urea -500 . 
Table.2 Effect of organic nitrogen management on quality and nutrienuptake of onion (pooled data over 2 years)

\begin{tabular}{|c|c|c|c|c|c|}
\hline \multirow[t]{2}{*}{ Treatments } & \multirow{2}{*}{$\begin{array}{l}\text { Pungency } \\
(\%)\end{array}$} & \multirow{2}{*}{$\begin{array}{l}\text { Carbohydrate } \\
(\%)\end{array}$} & \multicolumn{3}{|c|}{ Nutrient uptake $\left(\mathrm{kg} \mathrm{ha}^{-1}\right)$} \\
\hline & & & $\mathbf{N}$ & $\mathbf{P}_{2} \mathbf{O}_{5}$ & $\mathrm{~K}_{2} \mathrm{O}$ \\
\hline$T_{1}-100 \%$ RND as FYM & 0.0030 & 10.33 & 37.13 & 37.30 & 68.25 \\
\hline $\mathrm{T}_{2}-125 \%$ RND as FYM & 0.0039 & 10.45 & 38.07 & 37.88 & 69.97 \\
\hline$T_{3}-150 \%$ RND as FYM & 0.0043 & 10.66 & 38.89 & 38.70 & 71.48 \\
\hline $\mathrm{T}_{4}-100 \% \mathrm{RND}$ as VM & 0.0047 & 10.85 & 39.51 & 39.31 & 72.61 \\
\hline $\mathrm{T}_{5}-125 \% \mathrm{RND}$ as VM & 0.0058 & 10.92 & 40.23 & 40.02 & 73.93 \\
\hline $\mathrm{T}_{6}-150 \% \mathrm{RND}$ as VM & 0.0063 & 11.98 & 40.69 & 40.48 & 74.79 \\
\hline $\mathrm{T}_{7}-100 \% \mathrm{RND}$ as PM & 0.0067 & 11.05 & 41.13 & 40.92 & 75.56 \\
\hline $\mathrm{T}_{8}-125 \% \mathrm{RND}$ as PM & 0.0073 & 11.40 & 41.31 & 41.09 & 75.91 \\
\hline$T_{9}-150 \%$ RND as PM & 0.0077 & 11.88 & 42.03 & 41.81 & 77.23 \\
\hline $\begin{array}{l}\mathrm{T}_{10}-100 \% \mathrm{RND} \text { through } \\
\text { urea }\end{array}$ & 0.0015 & 10.15 & 36.67 & 36.48 & 67.39 \\
\hline SEm \pm & 0.001 & 0.70 & 0.17 & 0.16 & 0.8 \\
\hline C.D. (0.05) & 0.004 & NS & 0.49 & 0.64 & 0.53 \\
\hline
\end{tabular}


Table.3 Parameters as influenced by organic nitrogen nutrition at the end of 2 years cycle of onion.

\begin{tabular}{|c|c|c|c|c|c|c|c|c|c|c|}
\hline \multirow[t]{3}{*}{ Treatment } & \multicolumn{3}{|c|}{ Soil physical parameters } & \multicolumn{4}{|c|}{ Soil chemical parameters } & \multicolumn{3}{|c|}{ Soil biological parameters } \\
\hline & \multirow{2}{*}{$\begin{array}{l}\text { Bulk density } \\
\text { (g/cc) }\end{array}$} & \multirow[t]{2}{*}{ Porosity (\%) } & \multirow{2}{*}{$\begin{array}{l}\text { Water stable } \\
\text { aggregates } \\
(\%)\end{array}$} & \multirow{2}{*}{$\begin{array}{l}\text { Organic } \\
\text { Carbon }(\%)\end{array}$} & \multicolumn{3}{|c|}{ Available nutrient (kg/ha) } & \multirow{2}{*}{$\begin{array}{l}\text { Bacteria } \\
\left(\mathbf{x 1 0 ^ { 3 } )}\right.\end{array}$} & \multirow[t]{2}{*}{ Fungi $\left(x_{10}^{3}\right)$} & \multirow{2}{*}{$\begin{array}{l}\text { Actinomycete } \\
\text { s }\left(\mathbf{x 1 0}^{3}\right)\end{array}$} \\
\hline & & & & & $\mathbf{N}$ & $\mathbf{P}$ & $\mathbf{K}$ & & & \\
\hline $\begin{array}{l}T_{1}-100 \% \\
\text { RND as FYM }\end{array}$ & 1.36 & 40.32 & 18.01 & 0.44 & 184.34 & 24.43 & 154.41 & 62.82 & 22.5 & 33.73 \\
\hline $\begin{array}{l}T_{2}-125 \% \\
\text { RND as FYM }\end{array}$ & 1.37 & 40.38 & 18.18 & 0.45 & 185.46 & 24.61 & 154.87 & 63.63 & 23.03 & 34.74 \\
\hline $\begin{array}{l}T_{3}-150 \% \\
\text { RND as FYM }\end{array}$ & 1.39 & 41.34 & 18.2 & 0.46 & 186.72 & 25.44 & 155.44 & 66.92 & 24.00 & 35.43 \\
\hline $\begin{array}{l}T_{4}-100 \% \\
\text { RND as VM }\end{array}$ & 1.38 & 40.3 & 18.01 & 0.47 & 187.73 & 26.52 & 157.42 & 72.34 & 25.31 & 36.25 \\
\hline $\begin{array}{l}\mathrm{T}_{5}-125 \% \\
\mathrm{RND} \text { as VM }\end{array}$ & 1.4 & 40.36 & 18.2 & 0.48 & 189.44 & 27.82 & 158.84 & 77.94 & 27.94 & 37.44 \\
\hline $\begin{array}{l}T_{6}-150 \% \\
\text { RND as VM }\end{array}$ & 1.41 & 41.18 & 18.5 & 0.49 & 189.95 & 28 & 160.42 & 78.65 & 28.63 & 43.18 \\
\hline $\begin{array}{l}T_{7}-100 \% \\
\text { RND as PM }\end{array}$ & 1.39 & 40.2 & 18.04 & 0.5 & 190.44 & 28.42 & 161.72 & 79.54 & 29.45 & 46.94 \\
\hline $\begin{array}{l}T_{8}-125 \% \\
\text { RND as PM }\end{array}$ & 1.41 & 40.22 & 18.32 & 0.52 & 191.43 & 28.84 & 162.43 & 80.44 & 32.11 & 54.46 \\
\hline $\begin{array}{l}\mathrm{T}_{9}-150 \% \\
\mathrm{RND} \text { as PM }\end{array}$ & 1.42 & 40.95 & 18.65 & 0.54 & 192.98 & 29.43 & 164.12 & 82.45 & 37.82 & 58.23 \\
\hline $\begin{array}{l}T_{10}-100 \% \\
\text { RND through } \\
\text { urea }\end{array}$ & 1.35 & 40.02 & 18.00 & 0.4 & 178.95 & 22.44 & 152.44 & 41.85 & 11.49 & 33.44 \\
\hline Initial & 1.35 & 40.00 & 18.00 & 0.38 & 178.43 & 22.41 & 151.24 & 41.45 & 11.25 & 32.41 \\
\hline C.D. $(P=0.05)$ & NS & 0.86 & NS & 0.12 & 9.78 & 0.56 & 8.94 & - & - & - \\
\hline
\end{tabular}


Next best treatments in this respect were also found when PM applied with reduced rates of $125 \%$ and $100 \%$ RND, respectively. Continuous application of organic manures in sufficient quantities have been reported to improve the soil organic carbon and available $\mathrm{N}, \mathrm{P}$ and $\mathrm{K}$ in soil thereby sustaining the soil health (Tiwari et al., 2002).

Soil biological properties showed improvement in the soil microbial counts over its initial values at the end of 2-years cropping sequence due to supplementation of organic sources. Poultry manure applied @ 150\% RND was best which lead into higher counts of bacteria $\left(82.45 \times 10^{3}\right)$, fungi $\left(37.82 \times 10^{3}\right)$ and actinomycetes $\left(58.23 \times 10^{3}\right)$ closely followed by the treatments where PM was applied with reduced rates $\left(T_{8} \& T_{7}\right)$, respectively.

The control treatment $\left(\mathrm{T}_{10}\right)$ had relatively lower values of soil microbial count than the organic treatments. The favourable effect of organics on soil biological properties is a proven fact which helped in providing ideal conditions and presumably increased the microbial activity because of the available high organic matter. Hati et al., (2001) and Shanmei et al., (2002) also reported favourable effect of organic manures on soil physical and biological properties.

\section{Economics}

A perusal of data (Table 1) revealed that net return in onion was influenced to a great extent by organic manure. Data indicated that application of $100 \%$ RND as PM recorded highest net return (Rs. 74,233 ha-1) and benefit-cost ratio (2.33) over control (Rs. $36,202 \mathrm{ha}^{-1}$ and 1.58).

The monetary gain by application of $100 \%$ RND as PM was 105.05 per cent higher over inorganic treatment (control). Data further revealed that progressive increase in $\mathrm{N}$ levels decreased the net return of onion consequently application of $100 \%$ RND recorded higher net returns with application of all three sources of organic manure. Similar trend was observed in respect to benefit cost ratio.

\section{References}

Azad, B.S. and Lehria, S.K. (2001). Yield maximization of rice through integrated nutrient management under irrigated conditions. Ann. Agric. Res. New Series, 22(4): 471-475.

Babu, S., Marimuthu, R., Manivanna, V. and Ramesh Kumar, S. (2001). Effect of organic and inorganic manures on growth and yield of rice. Agril. Sci. Digest 21(4): 232-234.

Bhakher, J.R., Sharma, O.P. and Jat, B.C. (1997). Effect of nitrogen and farmyard manure on yield and yield attributes of barley (Hordeum vulgare) in a loamy sand soil. Ann. Agric. Research 18: 244-5.

Chhettri, M., Mandal, S.S. and Roy, B. (2002). Studies on the effect of sources of potassium and sulphur with or without farm yard manure on the yield components, grain yield and per cent disease index of rice under intensive cropping system. J. Interacademicia 6(1): 45-50.

Fageria, M.S. (2003). Text Book of Vegetable Crops Production Technology, II (Kalyani Publishers: Ludhiana, New Delhi, Noida (U.P.), Hyderabad, Chennai, Kolkata, Cuttack), p. 211-17.

Hati, K.M., Mandal, K.G., Mishra, A.K., Ghosh, P.K. and Acharya, C.L. 2001. Effect of irrigation regimes and nutrient management on soil water dynamics, evapo-transpiration and yield of wheat in vertisols. Indian Journal of Agricultural Sciences, 71(9): 581-87.

Hort, F.L. and Fisher, H.J. (1970). 
Determination of Pyruvic acid in dehydrated onion. In: Modern Food Analysis Springer Verlog, Berlin, Neidelberg, New York, pp. 433-434.

Loomis, W.E. and Shull, C.A. (1937). Methods in Plant Physiology McGrawHill Co., New York.

Shanmei, $\mathrm{Wu}$, Elaine, Ingham and Dunxiano, Hu 2002. (in) 17th World Congress of Soil Science held during 14-21 August 2002, Abstract Vol. V, p. 1756, Bangkok, Thailand.

Singh, B., Singh, Yadvinder and Meelu, O.P. (1996). Management of soil organic matter for maintained productivity in rice-wheat in India. In: Studies in Indian Agro-ecosystems (Pathak P.S. and Gopal B. eds.), National Institute of Ecology, p. 85-90.

Singh, Kalyan (2005). Final Annual Report Development of sustainable Farming system model for the Irrigated AgroEcosystem of Eastern UP, ICAR, Adhoc project, Department of Agronomy, I.A.Sci., B.H.U., Varanasi.

Tiwari, A., Dwivedi, A.K. and Diskhit, P.R. 2002. Long term influence of organic and inorganic fertilization on soil fertility and productivity os soybean wheat system in a vertisols. Journal of the Indian Society of Soil Science 50(4): 472-5.

Watson, C.A., Atkinson, D., Gosling, P., Jackson, L.R. and Rayns, F.W. (2002). Managing soil fertility in organic farming systems. Soil Use Management 18: 239-47.

Yadav, B.D., Khandelwal, R.B. and Sharma, Y.K. 2005. Use of bio-fertilizer (Azospirillum) in onion. Indian J. Hort. 62(2): 168-70.

\section{How to cite this article:}

Meena, R. N., Ashvin Kumar Meena and Kalyan Singh 2019. Yield, Quality, Economics and Nutrient uptake of Onion (Allium cepa L.) Influenced by Organic Nitrogen Management. Int.J.Curr.Microbiol.App.Sci. 8(10): 16-23. doi: https://doi.org/10.20546/ijcmas.2019.810.004 